\title{
CASE Study: The Acceptance of XYZ Bank's Mobile Banking Application Using Technology Acceptance Model (TAM)
}

\author{
Gabriella Juliani ${ }^{1 *}$,
}

Nike Taruna²,

Martha Anastasia Sibarani ${ }^{3}$,

Yenny ${ }^{4}$

1,2,3,4 Master Program, Department of Business Management, Binus Business School, Bina

Nusantara University, Jakarta, Indonesia

\begin{tabular}{|c|c|}
\hline ARTICLE INFO & ABSTRACT \\
\hline $\begin{array}{l}\text { ISSN: 2723-1097 } \\
\text { Keywords: } \\
\text { Technolooy acceptance } \\
\text { model; Mobile } \\
\text { banking; Customers } \\
\text { Attitude }\end{array}$ & $\begin{array}{l}\text { Nowadays, it is common for public to use information technology to support each } \\
\text { daily needs, such as mobile banking application. One of largest bank in Indonesia, } \\
\text { XYZ Bank provided mobile banking application to support customer in doing } \\
\text { financial and banking transaction. The case study was done to examine the } \\
\text { customer's acceptance of XYZ Bank's mobile banking application by using } \\
\text { Technology Acceptance Model (TAM), in order to provide information regarding } \\
\text { factors affecting customer's preference in using mobile banking application and } \\
\text { improve XYZ Bank's mobile banking application. This study was using } \\
\text { quantitative research strategy, in which data was collected by conducting online } \\
\text { survey towards XYZ Bank customer. Questionnaire was given in } 5 \text { point-scale. } \\
\text { Technology Acceptance Model (TAM) was conducted to examine the effect between } \\
\text { variables, such as: perceived ease of use, perceived usefulness, attitude towards } \\
\text { using, behavioral intention, actual use, and trust. The researcher found that all } \\
\text { indicators are reliable, based on its Cronbach's Alpha value which ranges between } \\
0.725 \text { (actual use) and O.924 (perceived ease of use). Data validity was tested and } \\
\text { shows the Chi-square difference ranges from } 69.716 \text { (between trust and perceived } \\
\text { usefulness) to 106.715. As conclusion, researcher concluded that all hypotheses are } \\
\text { accepted and each variable had positive effect towards other variable. }\end{array}$ \\
\hline
\end{tabular}

\section{Introduction}

Nowadays information technology is used to support every human daily routine. Based on Syarifuddin \& Viverita (2014) research, this trend not only in the foreign country but also Indonesia. BPS - Statistics Indonesia work along with Association of Internet Provider Indonesia reported the survey result which is internet user in Indonesia in 2013 reach 71,19 million people. It means that it has been increased from 2012 user, around 63 million users. In the condition of information technology which grow rapidly, bank service use the information technology as facilities to develop their service. The development that is used by bank service from information

Journal of Business and Management Review Vol. 2 No. 102021 Page 733-746

DOI: $10.47153 /$ jbmr210.2582021

*Corresponding Author

Email address: gabriella.juliani@binus.ac.id 
technology can be seen from the online service or application that provide from the bank, for example XYZ Bank's mobile banking application.

There're a lot of mobile banking and internet banking application that Indonesia's banks provide. One of them is XYZ Bank's mobile banking application. As one of the largest private bank in Indonesia, XYZ Bank's mobile banking application must compete with the other mobile banking or internet application. Bank transaction feature which can be found in this application are mobile banking and internet banking. Other than those two features, this application can also be used to check balance info and 10 latest transactions from electronic money card of XYZ Bank. Lately, customer also can create new bank account from this application. In the mobile banking section, it has some features, such as: balance and account status, fund transfer, electronic payment, e-commerce payment, card-less transaction, QR transfer, etc. Because of XYZ Bank's mobile banking application is user friendly, which is caused by the connection between electronic device with internet, so it will be interesting to know their consumer acceptance about this application.

Some benefits from XYZ Bank's mobile banking application are mobile banking transaction can be used through all GSM provider in Indonesia, the transaction is more efficient when using internet. When using payment and transfer features, there are features to help customer to save the payment list and transfer list so it can help customer to do their next transaction because they only need to choose from the payment list or transfer list. The application is practical and user friendly in the payment transaction and no need to input bank code when customer need to do bank across transfer. It is caused by the code of the bank which has been provided in the menu list. Further, XYZ Bank's mobile banking application support with security system which has been standardized from the bank itself. So when customer need to use mobile banking, they need to input verification code for access and password to start their transaction.

With all that much benefits from XYZ Bank's Mobile Banking Application, so we need to know about customer acceptance of XYZ Bank's Mobile Banking Application using Technology Acceptance Model (TAM). TAM method that has been developed by Davis, Bagozzi, \& Warshaw (1989) is a model to learn an individual acceptance of an information system. TAM can be used to explain and predict acceptability the information technology. Perceived usefulness and perceived ease of use are the factors that have any impact to the attitude. It means that behavioral intention can have a positive and substantial impact on the behavior in the actual condition (Liao, Hong, Wen, Pan \& Wu, 2018). In the same time, it means that TAM can be used to know employee's behavior to improve the work performance when adopting the new technology (Ahmad, 2018). 
Because there are so many benefits of the XYZ Bank's Mobile Banking Application that they have, so it may need to do further research about the people acceptance for this application. Acceptance itself acted as function of consumer aspect in system development (Taherdoost, 2017). This research is measure the impact of each variable in TAM model which consist of some variable, they are: perceived ease of use, perceived usefulness, attitude towards using, behavioral intention, actual use, trust.

Based on previous research which used TAM as method, there were 5 variables used in the research (Davis et al., 1989; Chen, Li, \& Li, 2012). In this research, we add the aspect of social behavior. Trust is introduced as the variable of this research because Trust, as cognitive action (Jayawarsa, Saputra, Jayanti, Kawisana, \& Aryawan, 2021) can help to know the effect of trust factor into customer behavior. Mobile banking user will be able to access information quickly, effectively, efficiently, as they are able to access banking world from any location, at any time, and any communication device (computer, smartphone or phone call). Customer's security and privacy are also provided and secured by the banks (Jayawarsa et al., 2021; Mada \& Putri, 2021). On the other hands, this flexibility will not prevent customer not to start worrying on mobile banking and internet banking service because mobile banking and internet banking have a gap to do criminal which is doing by someone who have specialty to use the system or cybercrime that can cause financial big lost. Trust is important variable for customer who is using XYZ Bank's Mobile Banking Application.

Purwanegara, Apriningsih, \& Andika (2013) investigated customer perception on mobile banking. Mobile transaction had a huge dependency on technology. Its system is equipped with an automatic protection since the registration to the usage. It involves PIN and listed phone number systems (Purwanegara et al., 2013; Koenaite, Maziriri, \& Chuchu, 2021), which resulted in assumption that mobile banking service is relatively safe because of its layered security. However, the safety of its system is in jeopardy when someone steals the phone or hack the account to access through the account (Purwanegara et al., 2013).

Considering some researchers focused on mobile banking and internet banking only, such as research of internet banking in Malaysia (Ariff, Yeow, Zakuan, Jusoh, \& Bahari, 2012), mobile banking in Thailand \& Australia (Mortimer, Neale, Hasan, \& Dunphy, 2015), mobile banking in India (Kumar, Lall, \& Mane, 2017), mobile banking in South Africa (Koenaite et al., 2021), we put this research focus onto the application which has mobile banking, internet banking and balance check of electronic wallet/money feature in the application. It will give the company information about factors that could affect customer interest while using XYZ Bank's Mobile Banking Application, as well as optimize the usage, bank transaction, and improve customer satisfaction. The customer of banks will use all the convenient way, such as online 
services more often, naturally goes with the important presence of internet as inseparable part of banking business (Vuković, Pivac, \& Kundid, 2019). Further, it will be beneficial for future researcher in improving information technology system such as mobile banking, internet banking, and customer acceptance, following the highly increasing trend of internet growth, multitasking demand, and high technologylifestyle.

\section{Literature Review}

\section{Mobile Banking}

Mobile banking application keeps evolving, as each bank competes to provide their best service for customer, as well as research conducted on mobile banking. It is said as one of innovative financial service delivered interactive bank services on the go ( $\mathrm{Ho}, \mathrm{Wu}$, Lee, \& Pham, 2020). Mobile banking streamlined mobile experience (Koenaite et al., 2021). Based on research done by Aldiabat, Al-Gasaymeh, \& Rashid (2019), service provided by banks have transformed in communication and information technology explosive growth. People can access bank service, not only limited to balance check and payment, but customer can also apply for credit, transfer between accounts and other dynamic transaction through mobile banking application. The customer ought to go to branch, service post, or ATM unit, but it has developed further that customer can access those banking service through application from any location and at any time (Aldiabat et al., 2019; Jayawarsa et al., 2021). This was once mentioned by Rizal and Munawir (2017) that mobile banking application is suitable for professional, regarding their busy and tight schedule. Service provided also varies, such as phone banking, SMS banking, and internet banking.

Ease of access and use were one of the reasons of consumer wide usage on mobile banking (Koenaite et al., 2021) Consumer acceptance of the technology and mobile banking itself will impact the satisfaction and success of banking system (Purwanegara et al., 2013). Younger generation such as Generation Z, which has adapted and depended on technology intensively, they had higher awareness of financial technology. Further, they will expect the future of mobile banking, it linked to how banks should take note and adapt to shift to customer habits and acceptance (Koenaite et al., 2021).

\section{Technology Acceptance Model (TAM)}

Technology Acceptance Model (TAM) is a method widely used to measure the technology acceptance and usage level (Davis et al., 1989). TAM itself is a model developed from Theory of Reasoned Action (TRA) (Fishbein \& Ajzen, 1975; Ajzen \& Fishbein, 1980; Muñoz-Leiva, Climent-Climent, Liébana-Cabanillas, 2017). This theory was developed by Martin Fishbein and Icek Ajzen, which explained that someone's 
behavior is pushed or affected by their behavioral intention (Fishbein \& Ajzen, 1975; Ajzen \& Fishbein, 1980; Muñoz-Leiva et al., 2017). Though this theory was developed for research purpose in sociology and psychology, this theory has been a foundation in investigating the behavior in information technology usage. Its model is used to identify and evaluate factors affecting individual behavior towards the acceptance of technology or information system (Wicaksono \& Maharani, 2020), as well as success or failure of adoption of new technologies (Raida \& Neji, 2013).

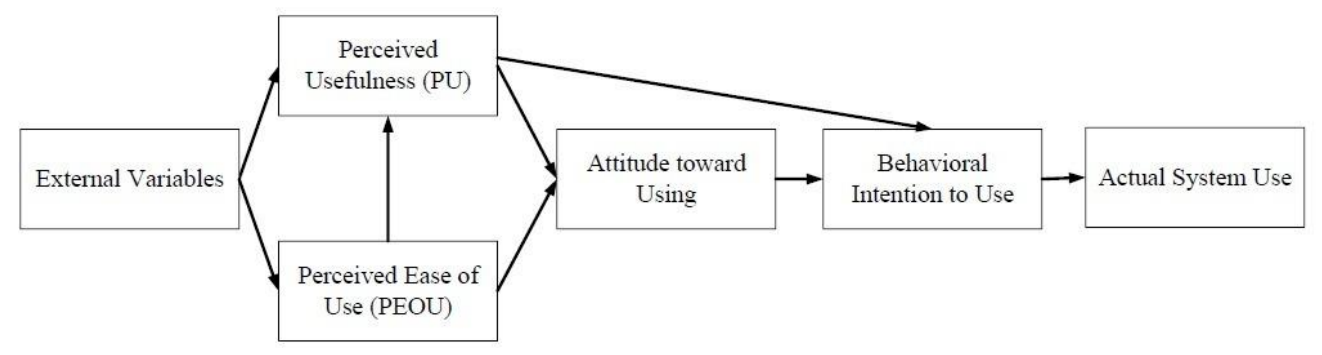

figure 1. Technology Acceptance Model (TAM)

(Chen et al., 2012)

Following Figure 1 above which was introduced in Chen et al. (2012) and adopted from Davis et al. (1989), perceived usefulness (PU) and perceived ease of use (PEOU) are the most direct factor and relevant to information system. This was also emphasized later in another research (Dehbini, Birjandi, \& Birjandi, 2015; Rotib, Silalahi, Adhiba, \& Narang, 2021).

Perceived Usefulness

Perceived usefulness is defined as the degree to which an individual believes that using a particular information system or information technology would enhance his or her job or life performance. Further, it means that the information technology would make work easier, increase productivity, increase work effectiveness, and performance (Ariff et al., 2012; Chen et al., 2012; Wicaksono \& Maharani, 2020).

H1: $\quad$ Perceived Usefulness has a positive effect towards Trust in using XYZ Bank's mobile banking application.

H5: Perceived Usefulness has a positive effect towards Attitude Towards Using in using XYZ Bank's mobile banking application.

H7: Perceived Usefulness has a positive effect towards Behavioral Intention in using XYZ Bank's mobile banking application.

Perceived Ease of Use

Perceived ease of use is the degree to which a person believes that using a particular information system or information technology would be free of effort. Further, it means the information technology would be easy to navigate, user-friendly 
interface, fast response, can be accessed from any location and at any time (Chen et al., 2012; Wicaksono \& Maharani, 2020).

H4: $\quad$ Perceived Ease of Use has a positive effect towards Perceived Usefulness in using XYZ Bank's mobile banking application.

H6: Perceived Ease of Use has a positive effect towards Attitude Towards Using in using XYZ Bank's mobile banking application.

The purpose of TAM is to provide traceability fundamental to identify the external factor towards trust, attitude and objective of the user. The main effects of individual acceptance behavior toward information technology are perceived usefulness and perceived ease of use (Rahayu, Budiyanto, \& Palyama, 2017). The other factors in TAM are attitude towards using, behavioral intention, and actual use.

\section{Attitude Towards Using}

Attitude towards using (ATU) can be defined as the pattern of initial response towards condition either it is nice or not on a certain object. The attitude can be sort of acceptance or even refusal (Rotib et al., 2021). Attitude itself it a reflection towards object, either it is in advantage or disadvantage. The attitude appears due to value set based on his or her trust towards the object (Rahayu et al., 2017). In short, it is customer's evaluation on desirability of using information technology system to support his or her need.

H2: Trust has a positive effect towards Attitude Towards Using in using XYZ Bank's mobile banking application.

H8: Attitude Towards Using has a positive effect towards Behavioral Intention in using XYZ Bank's mobile banking application.

Behavioral Intention

Behavior intention can be defined as individual intention or want to have a certain behavior or tendency in using or prefer an information technology system. It can be observed through his or her motivation in keep using it or use other technology and add supporting tools (Rahayu et al., 2017). In short, it is a measurement of customer likelihood to employ the information technology system.

H3: Trust has a positive effect towards Behavioral Intention in using XYZ Bank's mobile banking application.

H9: Behavioral Intention has a positive effect towards Actual Use in using XYZ Bank's mobile banking application.

Actual Use

Actual use can be defined as the real condition or application in which the information technology is used (Rahayu et al., 2017). TAM model can also use to adopt 
technology for information system and mobile banking. For developed and developing countries incorporated the theory of TAM to predict user to adopt technology for m-banking. Other than m-banking TAM also can be used for many new technologies from e-commerce, e-learning, internet banking, mobile payments, online gaming, social robot and etc have to examined and to validated the theory of TAM ( $\underline{\text { Ahmad, 2018) }}$.

\section{Method}

The study was conducted by using quantitative approach. Online survey was done on July 2019, which resulted in 91 samples consisting of 39 males and 52 females. Our respondents are the customer of XYZ Bank who were from various backgrounds, such as: banking industry, education, manufacturing industry, service, and other background. The survey was derived into 6 major topics following on TAM method (as illustrated in Figure 2), which was measured by 5-point scale: strongly disagree, disagree, neutral, agree, and strongly agree.

The hypotheses examination was done using Structural Equation Model (SEM) approach, to examine the causality between construct and items measured. Further, the validity of this study was examined using Structural Equation Model (SEM) and Confirmatory Factor Analysis (CFA).

\section{Result and Discussion}

A survey or questionnaire can be reliable if the answer given by respondent is consistent or stable. A construct is reliable if the Cronbach's Alpha value is more than 0.70. The Cronbach Alpha value is shown on Table 1.

Table 1. Convergent Validity and Reliablity

\begin{tabular}{cccc}
\hline Construct & Item & $\begin{array}{c}\text { Factor } \\
\text { Loading }\end{array}$ & $\begin{array}{c}\text { Cronbach's } \\
\text { Alpha }\end{array}$ \\
\hline \multirow{2}{*}{ Trust } & T1 & 0.759 & 0.799 \\
& T2 & 0.750 & \\
Perceived Usefulness & PU1 & 0.783 & 0.896 \\
& PU2 & 0.667 & \\
& PU3 & 0.764 & \\
Perceived Ease of Use & PEU1 & 0.843 & 0.924 \\
& PEU2 & 0.799 & \\
& PEU3 & 0.755 & \\
Attitude Towards Using & PEU4 & 0.805 & \\
& A1 & 0.827 & 0.883
\end{tabular}




\begin{tabular}{cccc}
\hline Construct & Item & $\begin{array}{c}\text { Factor } \\
\text { Loading } \\
\text { Behavioral Intention to Use }\end{array}$ & $\begin{array}{c}\text { Cronbach's } \\
\text { Alpha }\end{array}$ \\
& BI1 & 0.799 & \\
& BI2 & 0.795 & 0.894 \\
Actual Use & BI3 & 0.801 & \\
& U1 & 0.771 & 0.725 \\
& U2 & 0.561 & \\
\hline
\end{tabular}

Based on Table 1 shows, the value of Cronbach's Alpha ranges from 0.725 (actual use) to 0.924 (perceived ease of use). The table shows all indicators are reliable, based on its Cronbach's Alpha value which is more than 0.70 .

Table 2. CFA for Convergent Validity

\begin{tabular}{lccc}
\hline \multicolumn{1}{c}{ Construct } & $\begin{array}{c}\text { Chi- } \\
\text { square }\end{array}$ & $\begin{array}{c}P \\
\text { value }\end{array}$ & d.f. \\
\hline Recommended value & 77.725 & .0 .05 & \\
Trust & 138.769 & 0.000 & 5 \\
Perceived Usefulness & 96.418 & 0.000 & 6 \\
Perceived Ease of Use & 56.363 & 0.000 & 8 \\
Attitude Towards Using & 92.648 & 0.000 & 5 \\
Behavioral Intention & & 0.000 & 7 \\
\hline
\end{tabular}

Table 2 shows the result of Confirmatory Factory Analysis (CFA), regarding its purpose to analyze convergent validity. Data validity test is used to examine if there is correlation between construct. A survey/questionnaire is valid if the questionnaire is able to expose object which will be measure by using the questionnaire. Further, CFA Model is also used to analyze discriminant validity, which is shown in Table 3.

Table 3. Chi-square Difference Test

\begin{tabular}{|c|c|c|c|c|c|c|}
\hline & \multicolumn{2}{|c|}{$\begin{array}{l}\text { Model with Fixed } \\
\text { Correlation }\end{array}$} & \multicolumn{2}{|c|}{$\begin{array}{c}\text { Model with Freely } \\
\text { Estimated } \\
\text { Correlation }\end{array}$} & \multirow[b]{2}{*}{$\begin{array}{l}\text { Chi- } \\
\text { square }\end{array}$} & \multirow{2}{*}{$\begin{array}{c}\text { Chi- } \\
\text { square } \\
\text { Difference }\end{array}$} \\
\hline & d.f. & Chi-square & $\begin{array}{l}\text { Correlation } \\
\text { Coefficient }\end{array}$ & d.f. & & \\
\hline $\begin{array}{l}\text { Trust - perceived } \\
\text { usefulness }\end{array}$ & 30 & 94.551 & 0.591 & 29 & 28.436 & 69.716 \\
\hline $\begin{array}{l}\text { Trust - perceived } \\
\text { ease of use }\end{array}$ & 40 & 129.226 & 0.693 & 39 & 35.859 & 106.715 \\
\hline
\end{tabular}




\begin{tabular}{clc}
$\begin{array}{c}\text { Model with Fixed } \\
\text { Correlation }\end{array}$ & $\begin{array}{c}\text { Model with Freely } \\
\text { Estimated } \\
\text { Correlation }\end{array}$ & $\begin{array}{c}\text { Chi- } \\
\text { square } \\
\text { d.f. Chi-square }\end{array}$ \\
\hline $\begin{array}{l}\text { Correlation } \\
\text { Coefficient }\end{array}$ d.f. & $\begin{array}{c}\text { Chi- } \\
\text { square }\end{array}$ & Difference
\end{tabular}

Perceived

usefulness -

perceived ease of

48

133.381

0.672

47

39.260

98.698

use

Discriminant validity can be examined by looking into the Chi-square difference, in which Chi-square statistic in two models are tested and compared. Discriminant validity test is conducted between trust, perceived usefulness, and perceived ease of use. Table 3 shows the Chi-square difference ranges from 69.716 (between trust and perceived usefulness) to 106.715 (between trust and perceived ease of use). The differences are larger than 3.84 as threshold limit, which we can conclude that each construct pair is different.

\section{Assessment of Overall Model Fit}

After conducting reliability and validity test, Overall Model Fit was done to assess the data. The result of Overall Model Fit is shown on Table 4. Chi-Square statistic result is significant (chi-square $=508.692, \mathrm{P}=0.0$ ). Depends on Overall Model Fit index the result is over than the recommendation. It means the research model has shown the cause and effect relation.

Table 4. The Overall Model Fit

\begin{tabular}{lcc}
\hline & Score & $\begin{array}{c}\text { Recommended } \\
\text { Value }\end{array}$ \\
\hline Chi-square & 508.692 & .0 .05 \\
$P$ value & 0.000 & $>0.80$ \\
Degree of freedom & 85 & $>0.80$ \\
Goodness-of-fit index (GFI) & 0.815 & $<0.08$ \\
Adjusted goodness-of-fit index (AGFI) & 0.645 & 0.055 \\
Root mean square residual (RMSR) & & \\
\hline
\end{tabular}

\section{Assessment of Structural Model Fit}

Coefficient estimation causal between construct with objective to validate the effect of hypothesis can be shown on Figure 2. It is about coefficient estimated and the significant for structural model with $\mathrm{R}^{2}$ determinant coefficient for each construct. 


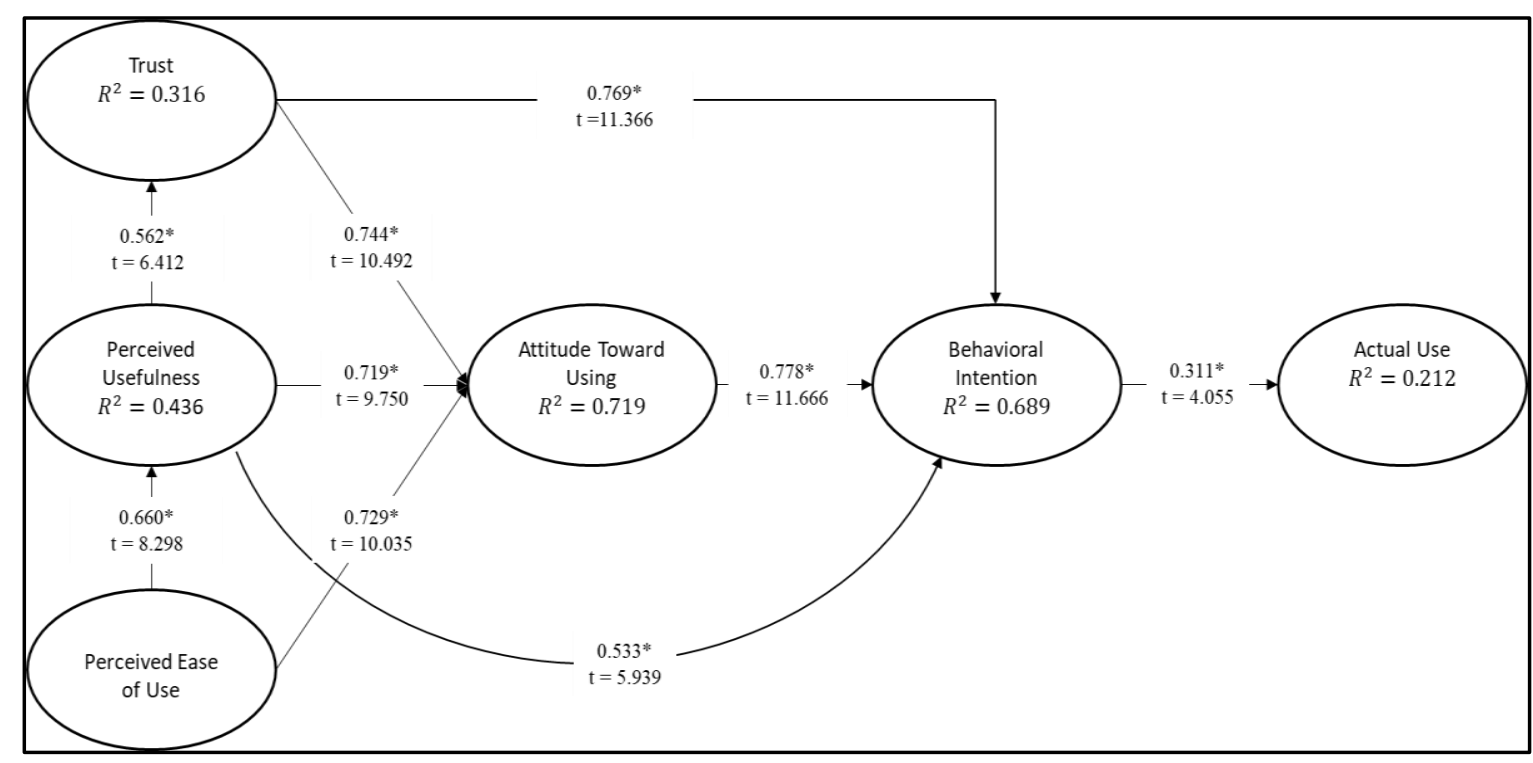

Figure 2. ESM Model

Hypothesis 1 and 4 found the effect of customer trust to the others are perceived usefulness to trust and perceived ease of us to perceived usefulness. Perceived usefulness has significant effect to trust $(\beta=0.562, \mathrm{t}=6.412, \mathrm{P}<0.01)$. It just aligned with statement that Primanda, Setyaning, Hidayat, \& Ekasasi (2020) give in their research. They were stated that perceived usefulness has a significant effect to consumer trust. Perceived ease of use has significant effect perceived usefulness $(\beta=$ $0.660, t=8.298, P<0.01)$. It just aligned with statement from Cho \& Sagynov (2015) that perceived ease of use has a supported effect to perceived usefulness. Hypothesis 1 and 4 are accepted.

Hypothesis 2, 5, and 6 are about the effect of customer trust to attitude toward using XYZ Bank's Mobile Banking Application. Trust affected attitude toward using of XYZ Bank's Mobile Banking Application $(\beta=0.744, \mathrm{t}=10.492, \mathrm{P}<0.01)$. Positive impact from perceived usefulness $(\beta=0.719, \mathrm{t}=9.750, \mathrm{P}<0.01)$ and perceived ease of use $(\beta=0.729, \mathrm{t}=10.035, \mathrm{P}<0.01)$ to attitude toward using. This result is aligned with the statement from Rahmiati \& Yuannita (2019) that trust and perceived ease of use can increase the attitude of consumer. Their research proved that the higher trust of the consumer, it can cause higher attitude of the consumer to the product. In the other research from Islami, Asdar, Baumassepe (2021), it is aligned with our result in this research that perceived usefulness and perceived ease of use supported attitude. Three of trust explain $72 \%$ of attitude toward using of XYZ Bank's Mobile Banking Application use $\left(R^{2}=0.719\right)$. Hypothesis 2,5 , and 6 are accepted.

Hypothesis 3,7 and 8, found impact of trust, perceived usefulness and attitude to behavioral intention of using XYZ Bank's Mobile Banking Application. 69\% of the 
behavioral intention variant to use XYZ Bank's Mobile Banking Application explained by trust, perceived usefulness and attitude toward using $\left(R^{2}=0.689\right)$. Attitude toward using has significant impact to behavioral intention $(\beta=0.778, \mathrm{t}=11.666$, $\mathrm{P}<0.01)$. Trust $(\beta=0.769, \mathrm{t}=11.366, \mathrm{P}<0.01)$ and perceived usefulness $(\beta=0.533, \mathrm{t}=$ $5.939, \mathrm{P}<0.01)$ have significant impact to behavioral intention. Perceived usefulness, attitude and trust significantly affected behavioral intention to use XYZ Bank's Mobile Banking Application. The result show that perceived usefulness and trust can be significantly affected the behavioral intention such as purchase intention. Perceived usefulness can affected behavioral intention because it can boost the trust to have behavioral intention (Primanda et al., 2020). The other result is related with research from Law, Kwok, \& Ng (2016) related to attitude that can be influenced behavioral intention such as purchase intention. Hypothesis 3, 7, and 8 are accepted.

Actual use from the customer of XYZ Bank's Mobile Banking Application affected by behavioral intention. Behavioral intention to use has positive impact to actual use of XYZ Bank's Mobile Banking Application at the 0,01 significant level ( $\beta=$ $0.311, \mathrm{t}=4.055)$. It is aligned with the research from Rattanaburi \& Vongurai (2021) that actual usage significantly influenced by behavioral intention. Hypothesis 9 is accepted.

\section{Conclusion}

From this research we can know that perceived usefulness has significant effect to trust. In the other side perceived ease of use supported effect to perceived usefulness. Trust has significant impact to XYZ Bank's Mobile Banking Application customer attitude (attitude towards using). Other than that, attitude also affected by perceived ease of use. Not only perceived ease of use, perceived of usefulness is also affected significantly to their attitude. Not only affected attitude, perceived usefulness can be significantly affected behavioral intention. Trust also has significant impact to behavioral intention. Behavioral intention to use of XYZ Bank's Mobile Banking Application was also affected by attitude. For actual usage can be significantly influenced by their behavioral intention.

The customer of XYZ Bank's Mobile Banking Application is depending on the XYZ Bank's Mobile Banking Application because of their trust and they also feeling safe to do banking transaction. Trust has important role in XYZ Bank's Mobile Banking Application use. The customer can feel more benefit while using the application such as fasten the banking transaction without going out to bank or queueing in office branch or ATM machine. The customer is also feeling easy to understand and fluent while using the features in XYZ Bank's Mobile Banking Application.

XYZ Bank's Mobile Banking Application is not specifically about mobile banking but also the internet banking. In this research discuss about the application 
which not specifically discuss about mobile banking or internet banking. For the suggestion in the next research can find out for each menu of the application. The other suggestion for the next research is can add some respondent from the other business field from bank industry, manufacturing industry and service. It was caused by the other group of business field in this research take 54,9\% from all the respondent.

Other than suggestion, researcher need to know the limitation from this research. TAM itself has some limitation such as for reporting TAM used self-reported data it means TAM is not use real and actual data. It can cause the subjective measurement because self-reported data may not reliable to predict the usage of the system itself. (Ahmad, 2018).

\section{References}

Ahmad, M. (2018). Review of The Technology Acceptance Model (TAM) in Internet banking and Mobile banking. International Journal of Information Communication Technology and Digital Convergence, 3(1), 23-41.

Ajzen, I., \& Fishbein, M. (1980). Understanding attitudes and pre-dicting social behavior. London: Prentice Hall International.

Aldiabat, K., Al-Gasaymeh, A., \& K.Rashid, A. S. (2019). The Effect of Mobile Banking Application on Customer Interaction in the Jordanian Banking Industry. International Journal of Interactive Mobile Technologies (IJIM), 13(02), 37. https:// doi.org/10.3991/ijim.v13i02.9262

Ariff, M. S. M., Yeow, S., Zakuan, N., Jusoh, A., \& Bahari, A. Z. (2012). The Effects of Computer Self-Efficacy and Technology Acceptance Model on Behavioral Intention in Internet Banking Systems. Procedia - Social and Behavioral Sciences, 57, 448-452. https://doi.org/10.1016/j.sbspro.2012.09.1210

Chen, S. C., Li, S. H., \& Li, C. Y. (2012). RECENT RELATED RESEARCH IN TECHNOLOGY ACCEPTANCE MODEL: A LITERATURE REVIEW. Australian Journal of Business and Management Research, 01(09), 124-127. https:// doi.org/10.52283/nswrca.ajbmr.20110109a14

Cho, Y. C., \& Sagynov, E. (2015). Exploring Factors That Affect Usefulness, Ease Of Use, Trust, And Purchase Intention In The Online Environment. International Journal of Management $\mathcal{E}$ Information Systems (IJMIS), 19(1), 21. https:// doi.org/10.19030/ijmis.v19i1.9086

Davis, F. D., Bagozzi, R. P., \& Warshaw, P. R. (1989). User Acceptance of Computer Technology: A Comparison of Two Theoretical Models. Management Science, 35(8), 982-1003. https:// doi.org/10.1287/mnsc.35.8.982

Dehbini, N., Birjandi, M., \& Birjandi, H. (2015). Factors Influencing the Adoption of Electronic Payment Cards in Urban Micro-Payments. Research Journal of Finance and Accounting, 6(1), 39-47.

Fishbein, M., \& Ajzen, I. (1975). Belief, attitude, intention andbehavior: An introduction to theory and research. Reading, MA:Addison-Wesley. 
Ho, J. C., Wu, C. G., Lee, C. S., \& Pham, T. T. T. (2020). Factors affecting the behavioral intention to adopt mobile banking: An international comparison. Technology in Society, 63, 101360. https:/ / doi.org/10.1016/j.techsoc.2020.101360

Islami, M. M., Asdar, M., \& Baumassepe, A. N. (2021). Analysis of Perceived Usefulness and Perceived Ease of Use to the Actual System Usage through Attitude Using Online Guidance Application. Hasanuddin Journal of Business Strategy, 3(1), 52-64. https://doi.org/10.26487/hjbs.v3i1.410

Jayawarsa, A. K., Saputra, K. A. K., Jayanti, L. G. P. S. E., Kawisana, P. G. W. P., \& Aryawan, G. (2021). A comprehensive overview on intelligent mechanical systems and its applications of mobile banking technology. Materials Today: Proceedings. Published. https:// doi.org/10.1016/j.matpr.2021.04.227

Koenaite, M., Maziriri, E., \& Chuchu, T. (2021). Attitudes Towards Utilising Mobile Banking Applications Among Generation Z Consumers in South Africa. Journal of Business and Management Review, 2(6), 417-438. https:// doi.org/10.47153/jbmr26.1452021

Kumar, V. R., Lall, A., \& Mane, T. (2017). Extending the TAM Model: Intention of Management Students to Use Mobile Banking: Evidence from India. Global Business Review, 18(1), 238-249. https:// doi.org/10.1177/0972150916666991

Law, M., Kwok, R. C. W., \& Ng, M. (2016). An extended online purchase intention model for middle-aged online users. Electronic Commerce Research and Applications, 20, 132-146. https:// doi.org/10.1016/j.elerap.2016.10.005

Liao, S., Hong, J. C., Wen, M. H., Pan, Y. C., \& Wu, Y. (2018). Applying Technology Acceptance Model (TAM) to explore Users' Behavioral Intention to Adopt a Performance Assessment System for E-book Production. EURASIA Journal of Mathematics, Science and Technology Education, 14(10). https:// doi.org/10.29333/ejmste/93575

Mada, I. G. N. C. W., \& Putri, P. Y. A. (2021). TECHNOLOGY ACCEPTANCE MODEL (TAM) UNTUK MENGANALISIS PENGGUNAAN ONLINE BANKING DI PT BANK RAKYAT INDONESIA, TBK. CABANG GIANYAR. Warmadewa Management and Business Journal (WMBJ), 3(1), 12-18. https:/ / doi.org/10.22225/wmbj.3.1.2021.12-18

Mortimer, G., Neale, L., Hasan, S. F. E., \& Dunphy, B. (2015). Investigating the factors influencing the adoption of m-banking: a cross cultural study. International Journal of Bank Marketing, 33(4), 545-570. https://doi.org/10.1108/ijbm-072014-0100

Muñoz-Leiva, F., Climent-Climent, S., \& Liébana-Cabanillas, F. (2017). Determinants of intention to use the mobile banking apps: An extension of the classic TAM model. Spanish Journal of Marketing - ESIC, 21(1), 25-38. https:/ / doi.org/10.1016/j.sjme.2016.12.001

Primanda, R., Setyaning, A. N., Hidayat, A., \& Ekasasi, S. R. (2020). The Role of Trust on Perceived Usefulness and Perceived Ease of Use toward Purchase Intention 
among Yogyakarta's Students. INOBIS: Jurnal Inovasi Bisnis Dan Manajemen Indonesia, 3(3), 316-326. https:/ / doi.org/10.31842/jurnalinobis.v3i3.140

Purwanegara, M., Apriningsih, A., \& Andika, F. (2014). Snapshot on Indonesia Regulation in Mobile Internet Banking Users Attitudes. Procedia - Social and Behavioral Sciences, 115, 147-155. https:/ / doi.org/10.1016/j.sbspro.2014.02.423

Rahayu, F. S., Budiyanto, D., \& Palyama, D. (2017). ANALISIS PENERIMAAN ELEARNING MENGGUNAKAN TECHNOLOGY ACCEPTANCE MODEL (TAM) (STUDI KASUS: UNIVERSITAS ATMA JAYA YOGYAKARTA). Jurnal Terapan Teknologi Informasi, 1(2), 87-98. https:// doi.org/10.21460/jutei.2017.12.20

Rahmiati, R., \& Yuannita, I. I. (2019). The influence of trust, perceived usefulness, perceived ease of use, and attitude on purchase intention. Jurnal Kajian Manajemen Bisnis, 8(1). https:// doi.org/10.24036/jkmb.10884800

Raida, R. E., \& Néji, B. (2013). The Adoption of the E-Banking: Validation of the Technology Acceptance Model. Technology and Investment, 04(03), 197-203. https:/ / doi.org/10.4236/ti.2013.43023

Rattanaburi, K., \& Vongurai, R. (2021). Factors Influencing Actual Usage of Mobile Shopping Applications: Generation $\mathrm{Y}$ in Thailand. Journal of Asian Finance, $\begin{array}{lll}\text { Economics } \text { and Business, 901-913. } & \text { 8(I), }\end{array}$ https:// doi.org/10.13106/jafeb.2021.vol8.no1.901

Rizal, S., \& Munawir. (2017). Pengaruh Kepuasan Nasabah Terhadap Menggunakan Mobile Banking (M-Banking) pada Bank BCA Cabang Banda Aceh. Retrieved from Jurnal Ekonomi dan Manajemen Teknologi, 1(2), 68-78. https:// doi.org/10.35870/emt.v1i2.34

Rotib, N. S., Silalahi, E. N., Adhiba, I. G., \& Narang, R. (2021). Factors that Affecting the Acceptance of People in Indonesia Towards the Use of Online Marketplace Technology. Journal of Business Management Review, 2(1), 023-037. https:/ / doi.org/10.47153/jbmr21.872021

Syarifudin, R., \& Viverita. (2014). Pengaruh Mobile Banking terhadap Kinerja Perbankan Indonesia. 1-24. Retrieved from http:/ / lib.ui.ac.id/naskahringkas/2016-06/S56851-Raynanda\%20Syarifudin

Taherdoost, H. (2018). A review of technology acceptance and adoption models and theories. Procedia Manufacturing, 22, 960-967. https:/ / doi.org/10.1016/j.promfg.2018.03.137

Vuković, M., Pivac, S., \& Kundid, D. (2019). Technology Acceptance Model for the Internet Banking Acceptance in Split. Business Systems Research Journal, 10(2), 124-140. https://doi.org/10.2478/bsrj-2019-022

Wicaksono, A., \& Maharani, A. (2020). The Effect of Perceived Usefulness and Perceived Ease of Use on the Technology Acceptance Model to Use Online Travel Agency. Journal of Business Management Review, 1(5), 313-328. https:/ / doi.org/10.47153/jbmr15.502020 